\title{
A Novel Thermostable and Alkaline Protease Produced from Bacillus stearothermophilus Isolated from Olive Oil Mill Sols Suitable to Industrial Biotechnology
}

\author{
Aida Karray ${ }^{1, *(D)}$, Mona Alonazi ${ }^{2}$ (D) Habib Horchani ${ }^{3}$ and Abir Ben Bacha ${ }^{2,4, *(D)}$ \\ 1 Laboratoire de Biochimie et de Génie Enzymatique des Lipases, ENIS Route de Soukra, \\ Université de Sfax-Tunisia, Sfax 3038, Tunisia \\ 2 Biochemistry Department, Science College, King Saud University, P.O. Box 22452, \\ Riyadh 11495, Saudi Arabia; moalonazi@ksu.edu.sa \\ 3 Groupe de Recherche en Environnement et Biotechnologie, Science Department, College of Rivière-Du-Loup, \\ Rivière-Du-Loup, Québec, QC G5R 1R1, Canada; habib.horchani@cegeprdl.ca \\ 4 Laboratory of Plant Biotechnology Applied to Crop Improvement, Faculty of Science of Sfax, \\ University of Sfax, Sfax 3038, Tunisia \\ * Correspondence: aida.karray@enis.tn (A.K.); aalghanouchi@ksu.edu.sa (A.B.B.); Tel.: +216-7467-5055 (A.K.); \\ +966-504-784-639 (A.B.B.)
}

check for updates

Citation: Karray, A.; Alonazi, M.; Horchani, H.; Ben Bacha, A. A Novel Thermostable and Alkaline Protease Produced from Bacillus stearothermophilus Isolated from Olive Oil Mill Sols Suitable to Industrial Biotechnology. Molecules 2021, 26, 1139. https://doi.org/10.3390/ molecules26041139

Academic Editor: Carlo Siciliano

Received: 30 December 2020

Accepted: 10 February 2021

Published: 20 February 2021

Publisher's Note: MDPI stays neutral with regard to jurisdictional claims in published maps and institutional affiliations.

Copyright: (c) 2021 by the authors. Licensee MDPI, Basel, Switzerland. This article is an open access article distributed under the terms and conditions of the Creative Commons Attribution (CC BY) license (https:/ / creativecommons.org/licenses/by/ $4.0 /)$.

\begin{abstract}
This study was conducted to identify a new alkaline and thermophilic protease (Ba.St.Pr) produced from Bacillus stearothermophilus isolated from olive oil mill sols and to evaluate its culture conditions, including temperature, $\mathrm{pH}$, carbon and nitrogen sources, and incubation time. The optimum culture conditions for cell growth $(10 \mathrm{~g} / \mathrm{L})$ and protease production $(5050 \mathrm{U} / \mathrm{mL})$ were as follows: temperature $55^{\circ} \mathrm{C}, \mathrm{pH} 10$, inoculation density $8 \times 10^{8} \mathrm{CFU} / \mathrm{mL}$, and incubation time $24 \mathrm{~h}$. The use of $3 \%$ yeast extract as the nitrogen sources and galactose $(7.5 \mathrm{~g} / \mathrm{L})$ as the carbon sources enhanced both cell growth and protease production. Using reversed-phase analytical HPLC on C-8 column, the new protease was purified with a molecular mass of approximately $28 \mathrm{kDa}$. The N-terminal sequence of Ba.St.Pr exhibited a high level of identity of approximately $95 \%$ with those of Bacillus strains. Characterization under extreme conditions revealed a novel thermostable and alkaline protease with a half-life time of $187 \mathrm{~min}$ when incubated with combined $\mathrm{Ca}^{2+} /$ mannitol. Ba.St.Pr demonstrated a higher stability in the presence of surfactant, solvent, and $\mathrm{Ca}^{2+}$ ions. Consequently, all the evaluated activity parameters highlighted the promising properties of this bacterium for industrial and biotechnological applications.
\end{abstract}

Keywords: protease; Bacillus stearothermophilus; characterization; thermostable

\section{Introduction}

Proteases are proteolytic enzymes that decompose proteins by hydrolyzing their peptide bonds. Although proteases are derived from different sources such as animals, plants, and microorganisms, microbial enzymes are characterized with simple and rapid production, independently of climatic conditions or seasonal changes [1-3]. In particular, production of extracellular proteases by microorganisms is more interesting than their intracellular production because this process simplifies the downstream processing, thereby further lowering the costs [4].

In the literature, several microorganisms are described as protease producers, such as Aspergillus oryzae [5], Serratia marcescens [6], and Bacillus subtilis [7]. The genus Bacillus is the most prominent source among all the investigated bacteria. This finding is related to the high capacity for protein secretion with more than $20 \mathrm{~g} / \mathrm{L}$ protein [8] and to the production of neutral and alkaline proteases $[9,10]$, which is an interesting aspect for enzyme use in industries [11,12]. 
In fact, proteases produced by Bacillus possess attractive characteristics for several industrial and biotechnological applications, realizing that they represent approximately $60 \%$ of the total worldwide enzyme sales. It is well documented that the proteases produced by Bacillus were largely used in the detergent industry owing to their extensive $\mathrm{pH}$ and temperature activity and stability range [13]. In particular, the enzymes applied in this industry should be able to preserve their activity in an alkaline environment and their stability in the presence of several toxic compounds, including oxidants and surfactants. Furthermore, proteases produced by Bacillus are potentially used in the food industry for obtaining bioactive peptides and processing diverse foods [14,15]. Another characteristic of proteases produced by Bacillus is their stability in organic solvents, due to which they have been applied during organic synthesis [16].

Therefore, the special industrial interest on organisms belonging to the genus Bacillus is first due to their rapid growth rates, permitting short fermentation cycles, and second due to their expressive ability for secreting significant amounts of proteins into the extracellular medium. Bacillus-derived proteases are generally alkaline with optimum $\mathrm{pH}$ activity values of $>7.0$. The biochemical description of these proteases has been a significant issue, considering their use and biochemical kinetic parameters. Consequently, the catalytic parameters of proteases, such as thermoresistance and tolerance to a diverse range of $\mathrm{pH}$ values, stability and activity of the enzyme, and further extreme reaction conditions, are commonly investigated for each potential enzyme. The molecular weight of Bacillus-derived proteases ranges from 27 to $71 \mathrm{kDa}$, with an optimal $\mathrm{pH}$ range between 6 and 10 and an optimal temperature obtained between $37^{\circ} \mathrm{C}$ and $60^{\circ} \mathrm{C}$. Moreover, the proteolytic enzymes exhibit significant stability values over a wide range of $\mathrm{pH}$ values and temperatures. Regarding their properties for use in biotechnological applications, bacterial proteases have been widely purified and characterized. As a result, their purity and homogeneity obviously allow determining the primary amino acid sequences and the 3D structures of proteases. Therefore, investigating the structure-function relationships of pure proteases can provide supplementary explanations about the kinetic parameters and characteristics of enzymatic catalyses [9]. Although there are several reports on the proteases produced by Bacillus, there is currently an increase in research on the identification of new strains producing preferment proteases from biological biotopes. In this study, we demonstrate the optimization of culture conditions, purification, and biochemical characterization of a novel thermostable and alkaline protease from Bacillus stearothermophilus isolated from olive oil mill sols and suitable to industrial biotechnology.

\section{Results}

2.1. Effect of Different Parameters on Cell Growth and Protease Production from B. stearothermophilus

\subsubsection{Effect of Temperature}

Culture temperature is considered as one of the essential factors influencing both bacterial growth and their capacity to produce protease enzymes. Therefore, Bacillus strain was grown at temperatures ranging from $30^{\circ} \mathrm{C}$ to $65^{\circ} \mathrm{C}$. In the present study, the isolated bacteria exhibited optimum cell growth at a temperature between $50{ }^{\circ} \mathrm{C}$ and $60{ }^{\circ} \mathrm{C}$ and maximum growth at $55^{\circ} \mathrm{C}(11.05 \mathrm{~g} / \mathrm{L} \pm 0.155)$. Similarly, the production of protease enzymes was achieved between $50^{\circ} \mathrm{C}$ and $60{ }^{\circ} \mathrm{C}$, with a maximal activity of $6885 \mathrm{U} / \mathrm{mL} \pm 91.923$ at $55^{\circ} \mathrm{C}$ (Figure 1B).

The ability of thermophilic bacteria to resist high temperatures can probably be explained by the activity in their metabolic functions associated with their physiological adaptations. 

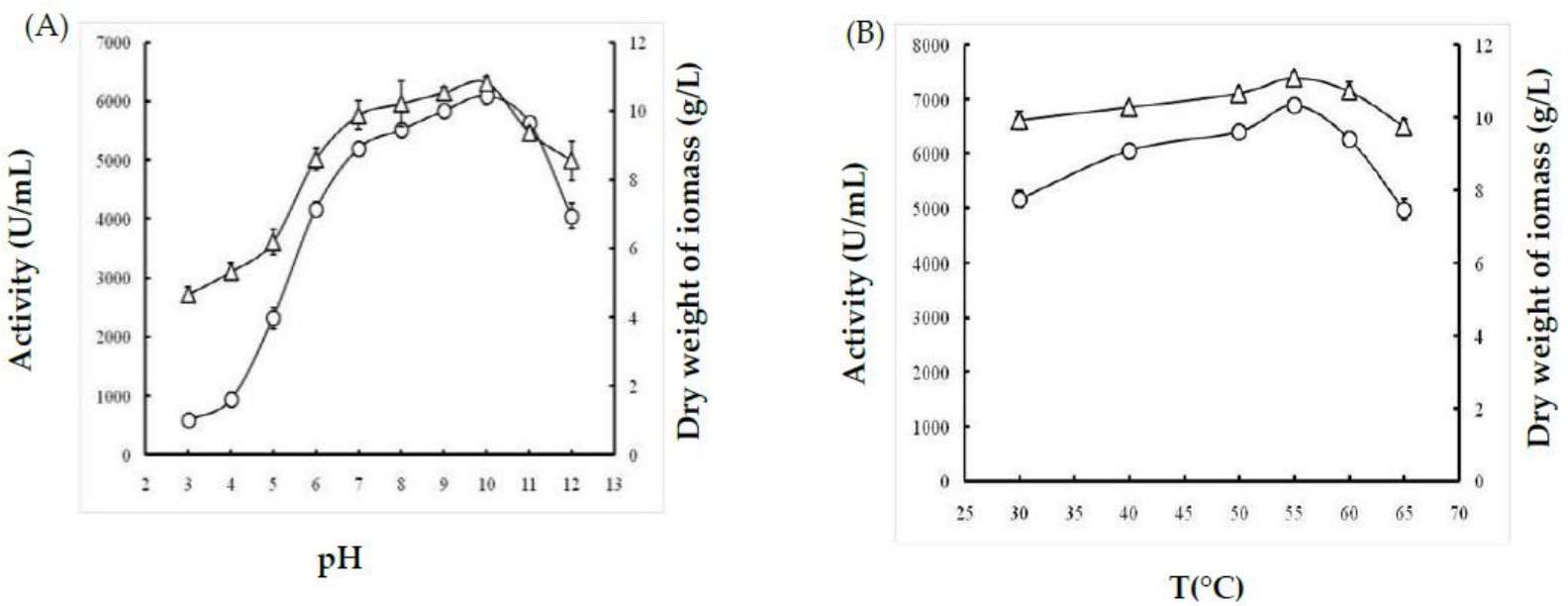

Figure 1. Effects of (A) temperature and (B) $\mathrm{pH}$ on growth (triangles) and protease production (bars) from Bacillus stearothermophilus. Data are expressed as mean $(n=3) \pm \mathrm{SD}$.

\subsubsection{Effect of $\mathrm{pH}$}

Evidently, the changes in $\mathrm{pH}$ values affected both cell growth and protease activity. In fact, it was observed that at acid $\mathrm{pH}$ values, the bacterial growth and protease productivity were extremely low ( $4.662 \mathrm{~g} / \mathrm{L} \pm 0.229$ and $597.5 \mathrm{U} / \mathrm{mL} \pm 24.748$, respectively) compared to those obtained at $\mathrm{pH}$ ranging from 7 to 11 . The highest dry weight of biomasses $(10.82 \mathrm{~g} / \mathrm{L} \pm 0.183)$ and protease activity $(6090 \mathrm{U} / \mathrm{mL} \pm 155.563)$ were observed at $\mathrm{pH} 10$ (Figure 1B). Consequently, the metabolic pathways of microorganisms were affected by $\mathrm{pH}$.

\subsubsection{Effects of the Carbon Source}

First, the effect of several carbon sources on protease activity and dry weight biomass was explored. The effects of casein, xylose, glucose, starch, lactose, glucose, and galactose were evaluated separately. Results shown in Figure 2A indicate comparable growth rates for most of the various carbon sources used in this study, except casein. Moreover, the protease activity was strongly influenced by the carbon sources. In fact, galactose permitted the highest protease activity of $8077 \mathrm{U} / \mathrm{mL} \pm 173$, followed by sucrose with a protease activity of $2647 \mathrm{U} / \mathrm{mL} \pm 144$. Next, the galactose concentration used in the culture media was optimized, with values ranging from 0 to $15 \mathrm{~g} / \mathrm{L}$. Figure $2 \mathrm{~B}$ shows that $7.5 \mathrm{~g} / \mathrm{L}$ galactose permitted the highest protease activity of approximately $9650 \mathrm{U} / \mathrm{mL}$ and the best biomass productivity of approximately $11.35 \mathrm{~g} / \mathrm{L}$. Beyond this galactose concentration, both the activity of protease and the cell growth were significantly decreased.

(A)

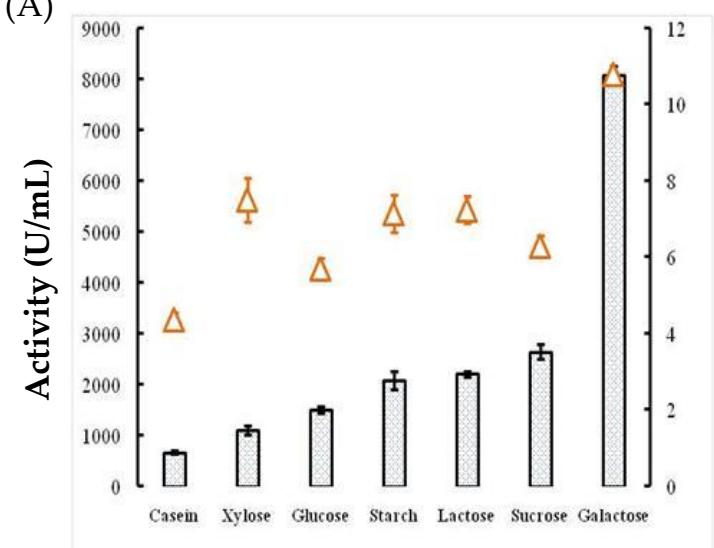

(B)

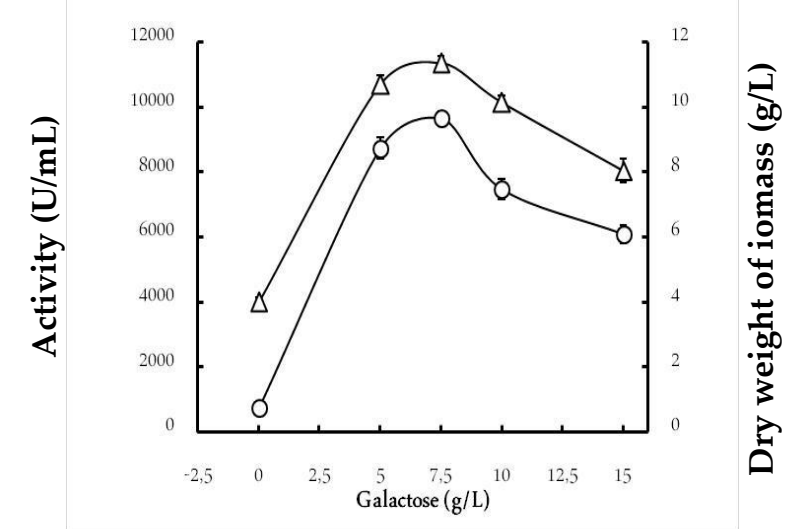

Figure 2. Effects of carbon source (A) and galactose concentration (B) on growth (triangles) and protease production (bars) from Bacillus stearothermophilus. Data are expressed as mean $(n=3) \pm \mathrm{SD}$. 


\subsubsection{Effects of Nitrogen Sources}

As described earlier, different organic and inorganic nitrogen sources $(1 \%)$ were evaluated for their effects on both growth and protease activity from the examined Bacillus. The curves shown in Figure 3A indicate that the use of yeast extract allowed maximum cell growth (10.525 g/L \pm 0.243$)$ and protease production $(7170 \mathrm{U} / \mathrm{mL} \pm 113.13)$. The protease activity appeared to be significantly affected by the various nitrogen sources. In fact, microorganisms require different specific nitrogen supplements for growth and metabolism. To better ameliorate enzyme productivity and biomass growth, the selected yeast extract was used at various concentrations ranging from $0 \%$ to $5 \%$ (Figure 3B). Evidently, the use of $3 \%$ yeast extract improved both proteolytic activity and dryweight biomass, with the values reaching $9050 \mathrm{U} / \mathrm{mL} \pm 212$ and $11.05 \mathrm{~g} / \mathrm{L} \pm 0.12$, respectively.

(A)

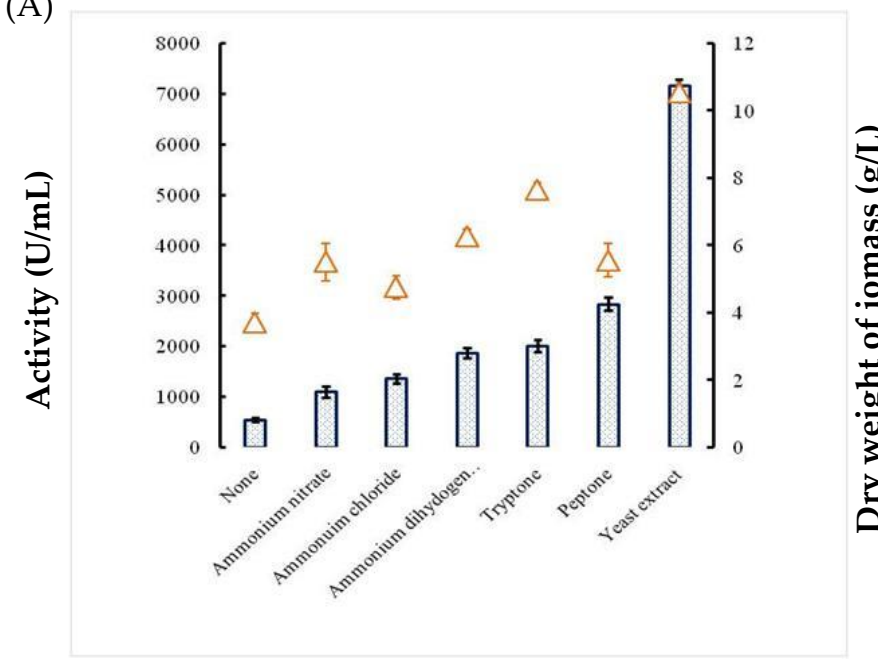

(B)

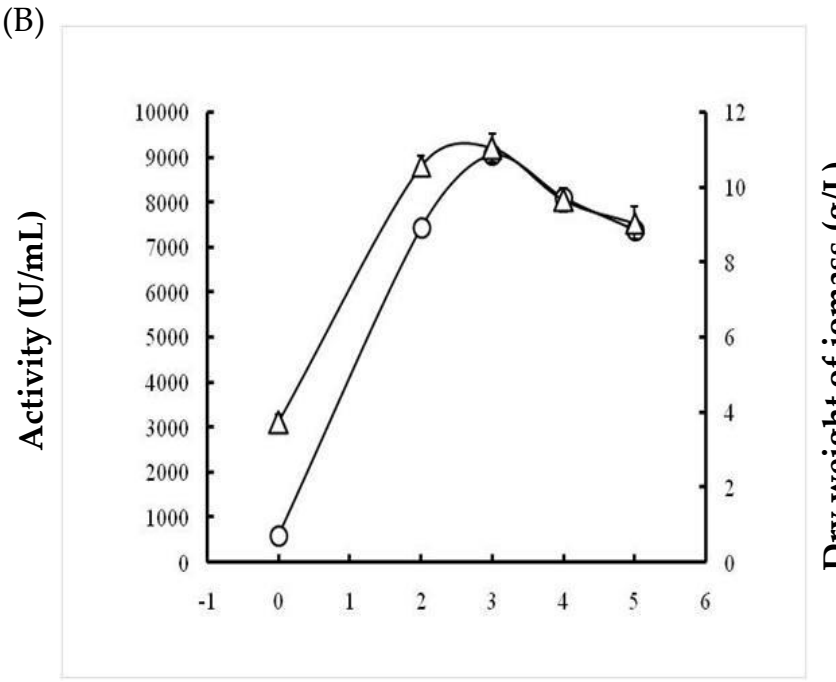

Figure 3. Effects of nitrogen source (A) and selected yeast extract concentration (B) on growth (triangles) and protease production (bars) from Bacillus stearothermophilus. Data are expressed as mean $(n=3) \pm \mathrm{SD}$.

\subsubsection{Effects of Incubation Time and Inoculum Size}

First, the effects of incubation time on bacterial growth and protease production were examined from 3 to $72 \mathrm{~h}$ and are presented in Figure $4 \mathrm{~A}$. The obtained curves revealed a significant increase in bacterial growth during the first few hours of bacterial culture, and the highest growth was observed at $24 \mathrm{~h}(10 \mathrm{~g} / \mathrm{L} \pm 0.8)$. In addition, protease production was proportional to cell growth, with an optimum value of $5100 \pm 212 \mathrm{U} / \mathrm{mL}$ obtained at $24 \mathrm{~h}$. Thereafter, there was a rapid decrease in protease activity and cell productivity by up to $72 \mathrm{~h}$ at a constant rate (Figure $4 \mathrm{~A}$ ). Next, the effect of inoculum size ranging from $10^{8}$ to $8 \times 10^{8} \mathrm{CFU} / \mathrm{mL}$ was examined during the culture period (Figure $4 \mathrm{~B}$ ). With all the tested inoculum sizes, the protease activity increased rapidly, reaching the maximum after $24 \mathrm{~h}$, and then decreased considerably. As shown in Figure 4B, the protease activity is proportional to the inoculum size tested, and the highest productivity $(5050 \mathrm{U} / \mathrm{mL})$ was observed with $8 \times 10^{8} \mathrm{CFU} / \mathrm{mL}$. Therefore, an extended inoculum size did not increase the enzyme productivity by B. stearothermophilus. 
(A)

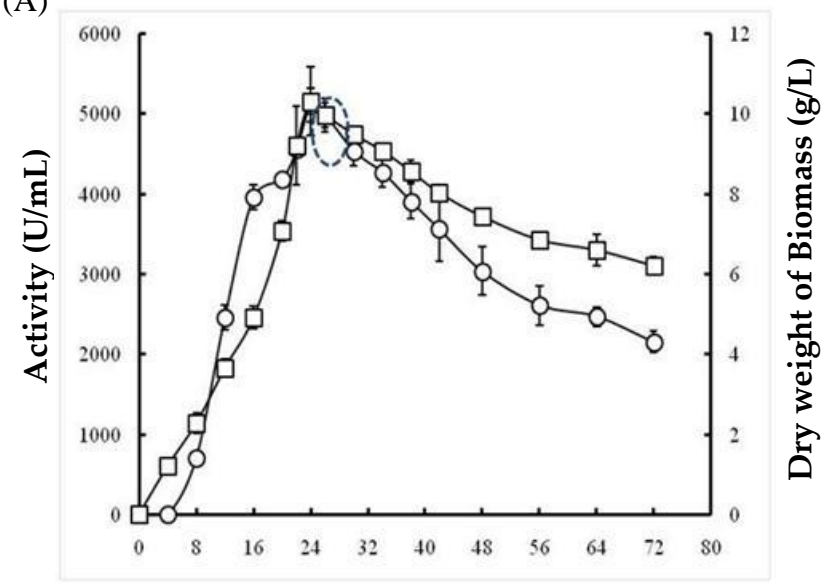

Time (h)
(B)

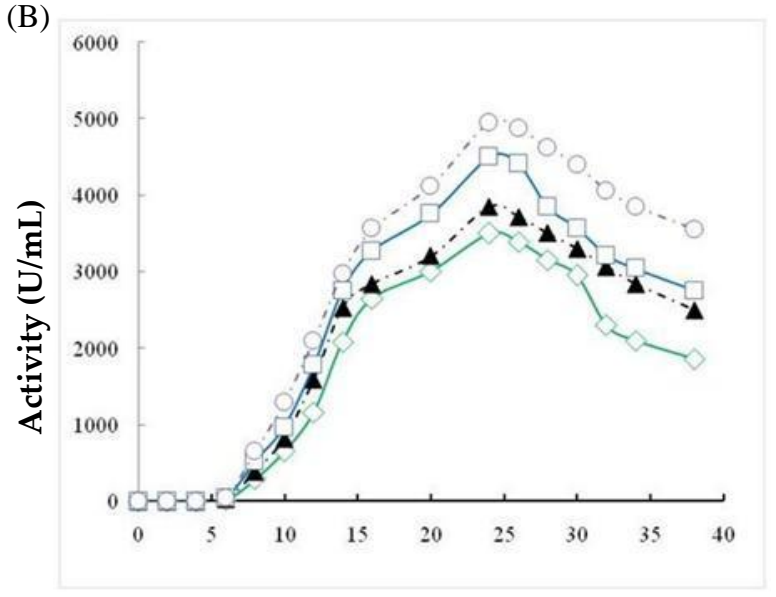

Time (h)

Figure 4. Effect of incubation time (A) on growth (white squares) and protease activity (white circles) and effect of inoculum size $\left(\right.$ B) on protease activity; (green line; $10^{8} \mathrm{CFU} / \mathrm{mL}$ ) (black line; $2 \times 10^{8} \mathrm{CFU} / \mathrm{mL}$ ) (blue line; $4 \times 10^{8} \mathrm{CFU} / \mathrm{mL}$ ) (purple line; $8 \times 10^{8} \mathrm{CFU} / \mathrm{mL}$ ).

\subsection{Purification Procedure of Ba.St.Pr and Determination of $\mathrm{NH}_{2}$-Terminal Amino Acid Sequence}

The Ba.St.Pr enzyme was purified from the optimized culture media supernatant as described in the materials and methods section. Briefly, after ammonium sulfate precipitation $(30-65 \%)$ and a heat treatment $\left(80{ }^{\circ} \mathrm{C}\right.$ for $\left.30 \mathrm{~min}\right)$, the obtained proteins were loaded onto a reversed-phase analytical HPLC on C 8 matrix equilibrated in water. The resulting protein elution profile indicated that the pure protease was eluted as a unique elution symmetrical peak at a retention time of $35 \mathrm{~min}$ using an acetonitrile linear gradient (0-80\%) at a flow rate of $1 \mathrm{~mL} / \mathrm{min}$ over $60 \mathrm{~min}$ (Figure 5A). The fractions exhibiting the protease activity emerged in a single peak at 35 min (Figure 5A). As summarized in Table 1, the purified Ba.St.Pr is characterized by a high specific activity of 59,022 U/mg under optimum assay conditions. Using the optimized procedure, $300 \mathrm{~mL}$ of culture media permitted the production of $26 \mathrm{mg}$ of pure enzyme. Next, SDS-PAGE was performed to analyze the purity of Ba.St.Pr (Figure 5B). The molecular mass of the purified enzyme was found to be approximately $28 \mathrm{kDa}$. The $\mathrm{NH}_{2}$-terminal amino acid sequence of Ba.St.Pr allowed the clear identification of 50 residues of the pure protease as follows: AQTVPYGIPQIKAPAVHAQGYKGANVKVAVLETGIHAAHPELNVAGGA (Figure 5C). The $\mathrm{NH}_{2}$-tertminal sequence exhibited high identity with those reported for proteases produced by several other Bacillus spp., reaching 95\% similarity with alkaline serine protease produced by B. altitudinis, alkaline protease produced by B. pumilus, serine alkaline protease produced by $B$. circulans, and serine protease produced by Alkalihalobacillus lehensis, with the accession numbers APZ77034.1, QJX57841.1, ADN04910.1, and AFP23380.1, respectively. These results strongly suggested that the Ba.St.Pr enzyme was a novel serine protease.

Table 1. Flow sheet for Ba.St.Pr purification (300 mL culture).

\begin{tabular}{cccccc}
\hline Purification Step & $\begin{array}{c}\text { Total Activity } \\
\text { (Units) }\end{array}$ & Protein (mg) & $\begin{array}{c}\text { Specific Activity } \\
\text { (U/mg) }\end{array}$ & $\begin{array}{c}\text { Activity } \\
\text { Recovery (\%) }\end{array}$ & $\begin{array}{c}\text { Purification } \\
\text { Factor }\end{array}$ \\
\hline Culture supernatant & $2,775,000$ & 3780 & 734 & 100 & 1 \\
$\left(\mathrm{NH}_{4}\right)_{2} \mathrm{SO}_{4}$ Precipitation $(30-65 \%)$ & $2,358,750$ & 1120 & 2106 & 85 & 2.87 \\
Heat treatment $\left(80{ }^{\circ} \mathrm{C}\right.$ for 30 min) & $2,090,500$ & 119 & 19,248 & 75.3 & 26.2 \\
RP-HPLC (C-8) & $1,534,575$ & 26 & 59,022 & 55.3 & 80.4 \\
\hline
\end{tabular}

One activity unit is defined as the amount of enzyme that hydrolyzed the substrate and produced $1 \mu \mathrm{g}$ of amino acid equivalent to tyrosine per minute under the experimental conditions used in this study. 
(A)

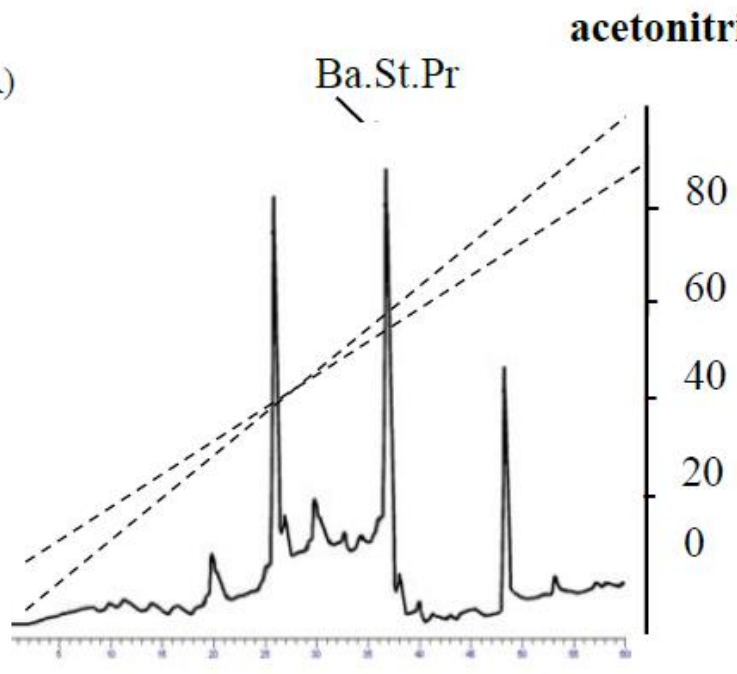

(B)

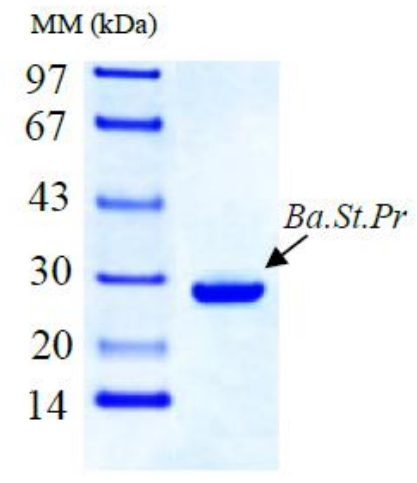

(C)

\section{AQTVPYGIPQIKAPAVHAQGYKGANVKVAVLETGIHAAHPELNVAGGA (Present Work)}

AQTVPYGIPQIKAPAVHAQGYKGANVKVAVLDTGIHAAHPDLNVAGGA APZ77034.1

AQTVPYGIPQIKAPAVHAQGYKGANVKVAVLDTGIHAAHPDLNVAGGA QJX57841.1

AQTVPYGIPQIKAPAVHAQGYKGANVKVAVLDTGIHAAHPDLNVAGGA $\underline{\text { ADN04910.1 }}$

AQTVPYGIPQIKAPAVHAQGYKGANVKVAVLDTGIHAAHPDLNVAGGA $\underline{\text { AFP23380.1 }}$

AQTVPYGIPQIKAPAVHAQGYKGANVKVAVLDTGIHAAHPDLNVAGGA WP 144525807.1

AQTVPYGIPQIKAPAVHAQGYKGANVKVAVLDTGIHAAHPDLNVAGGA WP 144484615.1

Figure 5. (A) Reversed-phase analytical HPLC on C8 matrix. Reversed-phase (RP)-HPLC eurospher 100, C-8 column $(250 \times 4.6 \mathrm{~mm})$, was equilibrated in water. Protein elution was performed with an acetonitrile linear gradient $(0-80 \%)$ at a flow rate of $1 \mathrm{~mL} / \mathrm{min}$ over $60 \mathrm{~min}$. $20 \mu \mathrm{L}$ of protease $(2 \mathrm{mg} / \mathrm{mL})$. (B) SDS-PAGE of pure Ba.St.Pr (10 $\mu \mathrm{g})$. (C) Local alignment of the Ba.St.Pr N-terminal sequence (present work) with the highest identity protease sequences from Bacillus strains. Identical amino acids in bold and different amino acids are in red.

\subsection{Effects of Extreme $\mathrm{pH}$ and Temperature on Protease Activity and Stability}

Results shown in Figure 6A indicate that Ba.St.Pr exhibited high relative activity at $\mathrm{pH}$ values ranging from 7 to 12 , with an optimum activity at $\mathrm{pH} 10$. However, at $\mathrm{pH} 5$ and 13, the relative activities were approximately $50 \%$. Moreover, we interestingly noticed that the purified enzyme was strongly stable in the $\mathrm{pH}$ range of $7-11$ after $2 \mathrm{~h}$ of incubation. The enzyme retained $89 \%$ and $82 \%$ of its activity at $\mathrm{pH} 6$ and 12 , respectively, under the same conditions. To better characterize and evaluate the $\mathrm{pH}$ stability, the enzyme was incubated at $\mathrm{pH}$ from 7 to 13 at various time periods from 0 to $36 \mathrm{~h}$. At $\mathrm{pH}<9$, the enzyme retained $90 \%$ of its initial activity for an incubation time of $20 \mathrm{~h}$. At $\mathrm{pH} 10$, it remained stable (90\%) for $10 \mathrm{~h}$. Moreover, at $\mathrm{pH}>10$, the stability of Ba.St.Pr reached $80 \%$ after $4 \mathrm{~h}$ of incubation (Figure 6B).

Ba.St.Pr was fully active at $60^{\circ} \mathrm{C}$ and $65^{\circ} \mathrm{C}$ in the absence of $\mathrm{CaCl}_{2}$, at $\mathrm{pH} 10$, and using casein as substrate. Interestingly, the protease activity was much higher when incubated with $3 \mathrm{mM}$ calcium. In fact, the relative activity increased by approximately $50 \%$ and $127 \%$ at $60{ }^{\circ} \mathrm{C}$ and $70{ }^{\circ} \mathrm{C}$, respectively (Figure $6 \mathrm{C}$ ). Even at the highest temperature tested, Ba.St.Pr was fully active, and there was an increase in its activity by $38 \%$ at $80^{\circ} \mathrm{C}$. Moreover, to better characterize the enzyme stability at extreme temperatures, the residual activity was measured after incubations at $80^{\circ} \mathrm{C}$ and $90{ }^{\circ} \mathrm{C}$ with $3 \mathrm{mM} \mathrm{Ca}^{2+}$ or with a combination of $\mathrm{Ca}^{2+}$ and mannitol for time intervals of 1-6 h. Evidently, as shown in Figure 6D, Ba.St.Pr 
is extremely stable as it retained its activity at $80^{\circ} \mathrm{C}$ for $4 \mathrm{~h}$ combined to its activity obtained with $\mathrm{Ca}^{2+}$ and mannitol combination. In fact, both calcium and mannitol significantly improved the thermal stability of the enzyme as it remained active $(90 \%)$ at $90{ }^{\circ} \mathrm{C}$. The half-life time deduced from Figure $6 \mathrm{D}$ was approximately $123 \mathrm{~min}$ at $80^{\circ} \mathrm{C}$ for Ba.St.Pr alone; however, it improved to 166 and $187 \mathrm{~min}$ when the enzyme was incubated with $\mathrm{Ca}^{2+}$ and the combination of $\mathrm{Ca}^{2+} /$ mannitol, respectively.

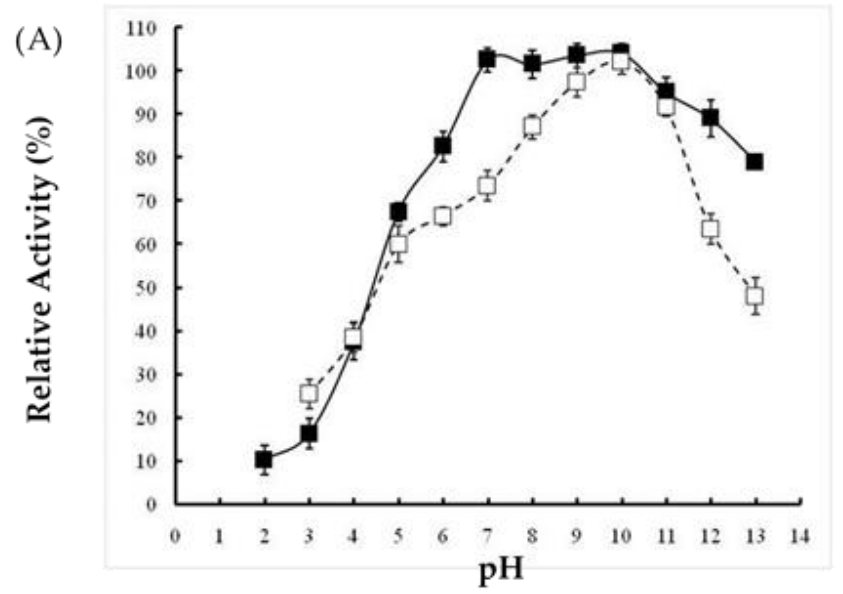

(B)
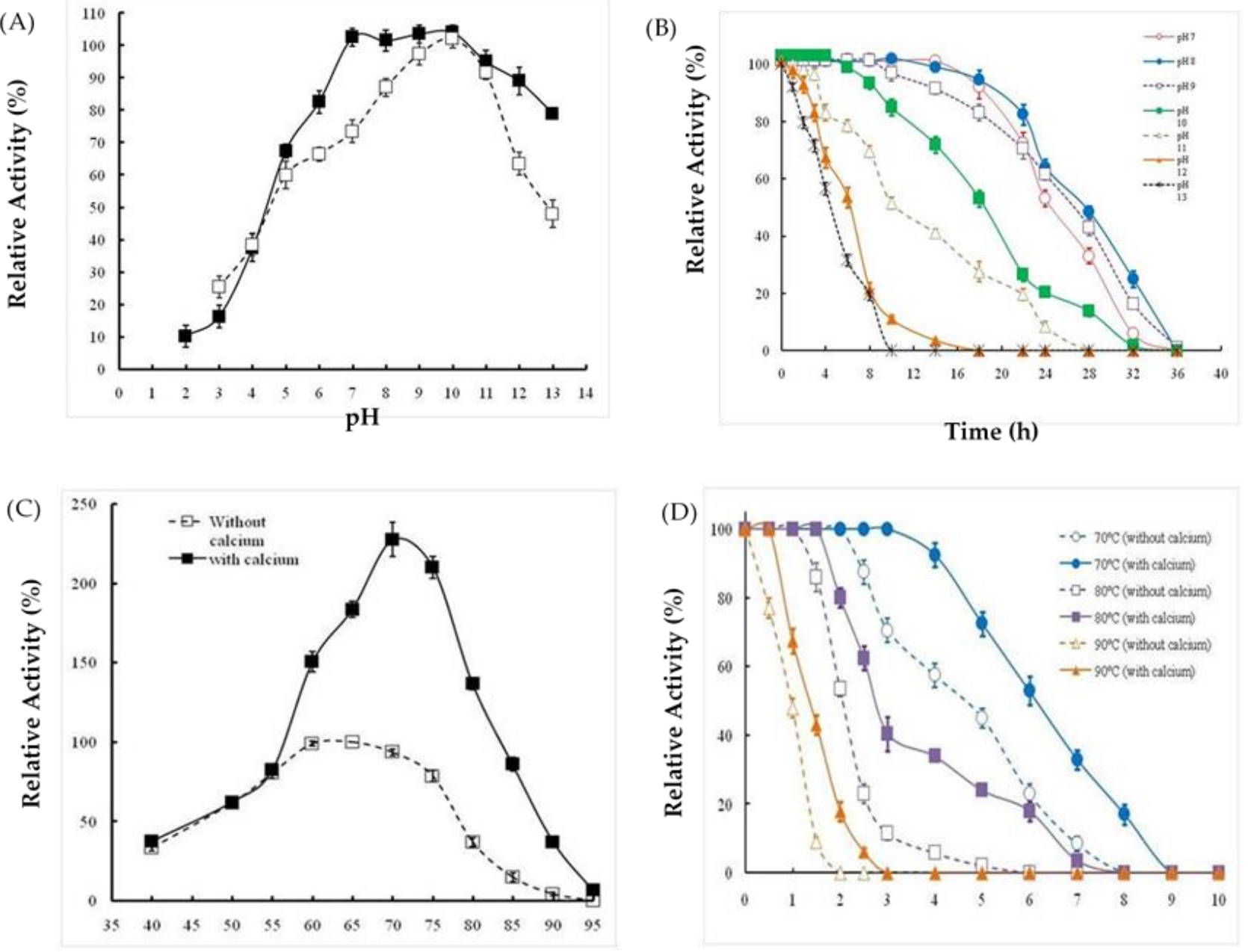

Temperature ${ }^{\circ} \mathrm{C}$

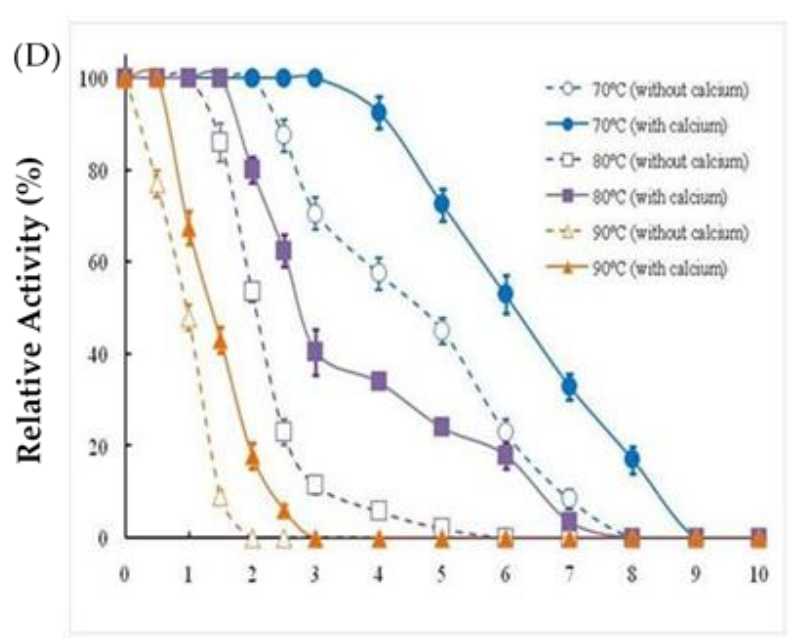

Time (h)

Figure 6. Evaluation of $\mathrm{pH}$ effect on the activity (white squares) and stability (black squares) of Ba.St.Pr. (A). Effect of alkali $\mathrm{pH}$ on Ba.St.Pr stability at various incubation times from 0 to $36 \mathrm{~h}(\mathbf{B})$. Evaluation of the effect of temperature on protease activity without $\mathrm{Ca}^{2+}$ ions (white squares) and with $\mathrm{Ca}^{2+}$ ions (black squares) of Ba.St.Pr. (C). Effect of extreme temperatures on Ba.St.Pr stability at various incubation times from 0 to $10 \mathrm{~h}$ (D).

\subsection{Effects of Surfactants, Oxidizing Agents, Organic Solvents, and Ions on Ba.St.Pr Stability}

When Ba.St.Pr was preincubated in the presence of several commercially ionic and nonionic surfactants, natural surfactants, and denaturing agents, its activity and stability increased compared with the negative control. A higher stability was observed in the presence of Triton X-100, Tween 20, or Tween 80, with the residual activities being 140\%, 130\%, and $120 \%$, respectively. Ba.St.Pr retained $90 \%, 86 \%$, and $82 \%$ of its activity after treatment with sodium perborate, $\mathrm{H}_{2} \mathrm{O}_{2}$, and sodium hypochlorite, respectively. However, Alcalase $2.5 \mathrm{~L}$, type DX, retained $60 \%$ of its initial activity after a similar treatment (Figure 7A,B). Moreover, the stability of proteases in organic solvents is an important feature to discuss about its application during organic synthesis. Hence, several solvents were tested for protease stability. As shown in Figure 7C, the enzyme Ba.St.Pr was remarkably stable 
in chloroform and ethanol as it expressed $160 \%$ of its activity, followed by that in DMF, isopropanol, and DMSO, with the residual activity being $100 \%$. For further comparison, the stability of Ba.St.Pr was found to be almost higher than that of commercial Alcalase 2.5 L, type DX. Several divalent metallic ions were evaluated for their effects on Ba.St.Pr activity (Figure 7D). There was a remarkable improvement in its activity by $149 \%, 72 \%$, and $68 \%$ with $\mathrm{CaCl}_{2}, \mathrm{MgCl}_{2}$, and $\mathrm{CoCl}_{2}$, at $3 \mathrm{mM}$ concentration, compared with the control, respectively. Moreover, the enzyme was slightly activated by $\mathrm{Cu}^{2+}, \mathrm{Mn}^{2+}$, and $\mathrm{Zn}^{2+}$ but completely inactivated by $\mathrm{Ni}^{2+}, \mathrm{Hg}^{2+}$, and $\mathrm{Co}^{2+}$.

(A)

(C)
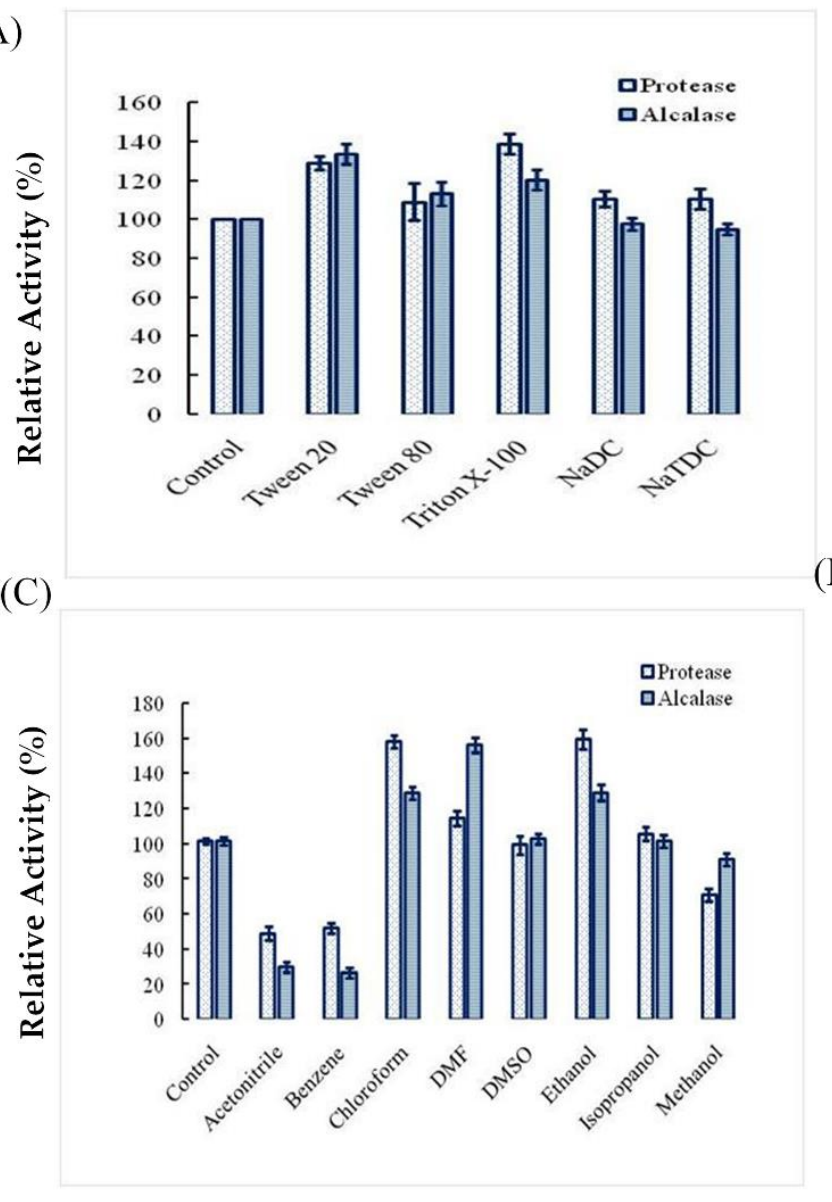

(B)

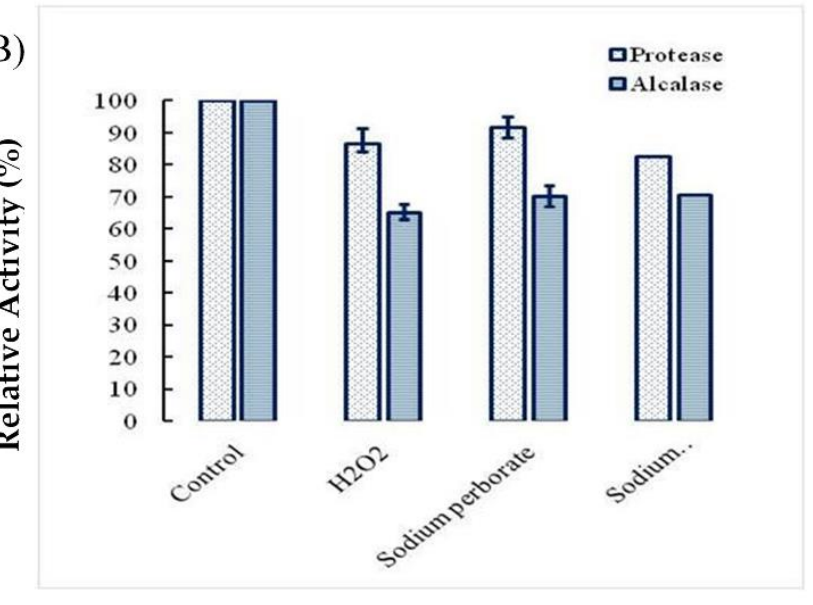

(D)

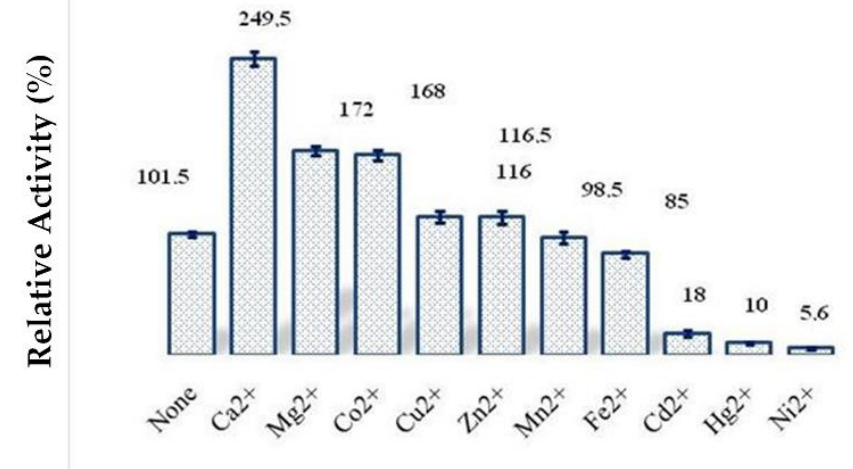

Figure 7. Effects of surfactants (A), oxidizing agents (B), organic solvents (C), and divalent ions (D) on Ba.St.Pr stability. The enzyme was incubated with the appropriate agent for $1 \mathrm{~h}$, and the residual activity was measured at the optimal conditions. A commercial Alcalase $2.5 \mathrm{~L}$, type DX, was used as a positive control.

\subsection{Stability and Compatibility of Ba.St.Pr with Solid and Liquid Commercial Laundry Detergents}

The data shown in Figure 8A,B indicate that compared with Alcalase 2.5 L, type DX, Ba.St.Pr is almost extremely stable and compatible with the commercial liquid and solid laundry detergents used in this study. In fact, it retained $100 \%$ of its initial activity with several solid detergents and $90 \%$ with liquid detergents. However, the residual activities of Alcalase $2.5 \mathrm{~L}$, type DX, were $70 \%$ and $60 \%$ with solid and liquid detergents, respectively. 
(A)

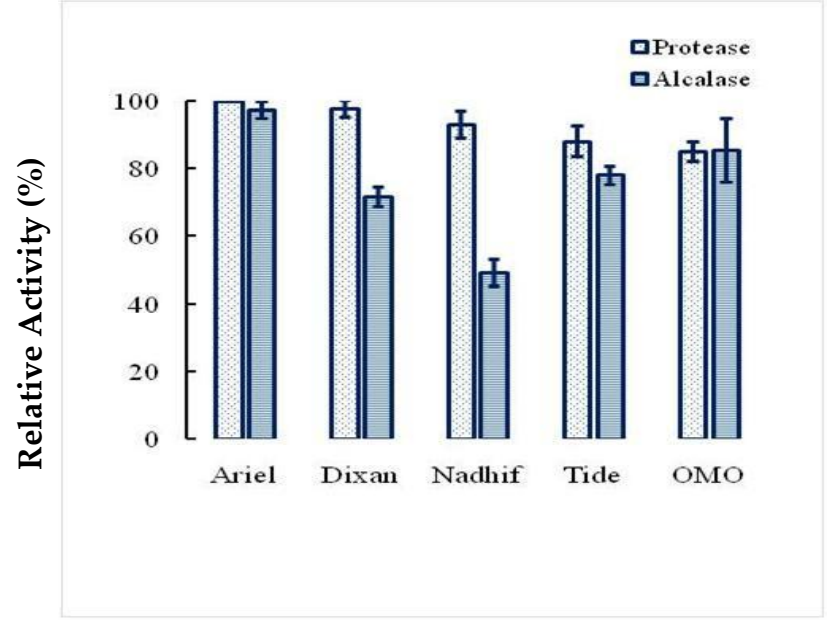

(B)

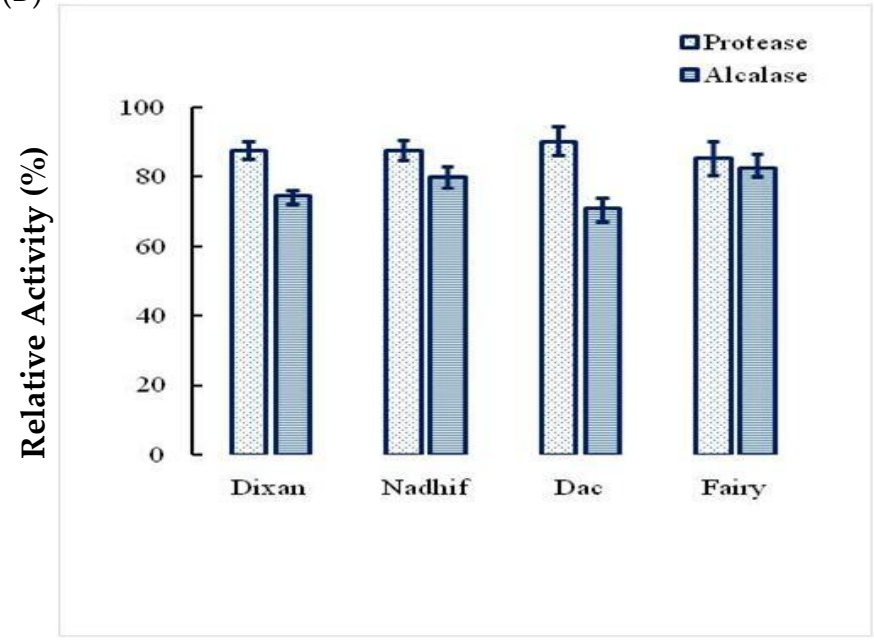

Figure 8. Stability and compatibility of Ba.St.Pr with solid (A) and liquid (B) commercial laundry detergents compared with commercial Alcalase $2.5 \mathrm{~L}$ measured under the same conditions.

\section{Discussion}

The use of thermostable enzymes in several industrial processes or biotechnological applications has several virtues compared with mesophilic enzymes. In fact, thermoenzymes are more resistant to thermal and chemical denaturations than mesoenzymes. These properties allow their usage in extreme conditions wherein their mesophilic equivalents would be less efficient. The thermostability properties of thermophilic enzymes have attracted the interest of several industrial sectors. In fact, thermoenzymes are generally used in the pulp and paper, food, pharmaceutical, detergents, and organic synthesis industries. Proteases, cellulases, amylases, and lipases are among the most sought-after thermophilic enzymes in these sectors of activity.

Moreover, several Bacillus strains are capable of producing a large amount of industrially interesting alkaline and neutral proteases $[10,17]$.

The optimization of Bacillus bacterial protease production includes several parameters and starts by determining the effect of temperature on both bacterial growth and their capacity to produce protease enzymes. In this study, the isolate B. stearothermophilus isolated from olive oil mill sols demonstrated maximum growth at $55^{\circ} \mathrm{C}(11.05 \mathrm{~g} / \mathrm{L} \pm 0.155)$ and a maximum activity of $6885 \mathrm{U} / \mathrm{mL} \pm 91.923$ at $55^{\circ} \mathrm{C}$. Similarly, the optimum growth of some Geobacillus sp. was attained between $30{ }^{\circ} \mathrm{C}$ and $70{ }^{\circ} \mathrm{C}$ with the maximum activity at $60^{\circ} \mathrm{C}$ [18]. However, it has been reported that the optimum temperature was speciesdependent for protease production [19]. Furthermore, the $\mathrm{pH}$ of the culture medium is an important criterion for the ability of the microorganism to produce extracellular protease. In fact, the catalytic reaction strongly depends on the charge distribution of substrates and enzyme molecules [20]. It was observed that at acid $\mathrm{pH}$ values, the bacterial growth and protease productivity were very low compared with results obtained at $\mathrm{pH}$ ranging from 7 to 11 . The highest dry weight of biomasses $(10.82 \mathrm{~g} / \mathrm{L} \pm 0.183)$ and protease activity (6090 U/mL \pm 155.563$)$ were observed at $\mathrm{pH} 10$. Similarly, the majority of investigated Geobacillus spp. have their growth at a $\mathrm{pH}$ range of 6-9 for the production of protease [21]. However, the maximum growth and protease production by Bacillus sp. were achieved at pH 8 [22]. We clearly noticed a relationship between the growth of bacteria and their production of the protease enzyme with regard to temperature and $\mathrm{pH}$ optimization. It is well established that carbon and nitrogen sources significantly affect the cell growth and protease production from bacterial strains. The ability of an organism to break down different carbohydrates could be a result of its preference towards living in an environment containing low in organic, and therefore the need to develop its metabolic system to adjust assimilate [23]. In fact, in the present study, galactose permitted the highest protease 
activity of $8077 \mathrm{U} / \mathrm{mL} \pm 173$, followed by sucrose with $2647 \mathrm{U} / \mathrm{mL} \pm 144$. Compared with several studies, further carbohydrates were found to increase the production yield of alkaline protease. In fact, Malathi and Chakraborty [24] confirmed that maltose allows the highest protease production yield. Similarly, Tsuchiya et al. [25] reported the use of maltose as a good carbon source for high production of the protease enzyme. Sucrose and fructose have also been described to improve protease production [26]. Glucose is frequently used as a carbon source to produce protease enzymes through fermentation. However, results from different investigations have shown that the production of protease enzyme was reduced by glucose due to glucose catabolic repression [27]. Accordingly, the curves obtained in this study compared with the effect of nitrogen sources showed that the use of yeast extract $(1 \% w / v)$ allowed the maximum cell growth $(10.525 \mathrm{~g} / \mathrm{L} \pm 0.243)$ and protease production $(7170 \mathrm{U} / \mathrm{mL} \pm 113.13)$. In fact, yeast extract is considered as a good source for the maximum production of protease due to its richness of amino acids, various vitamins, and carbohydrates to improve both the cell growth and metabolic functions of the bacterium [28]. Evidently, the use of 3\% yeast extract improved the proteolytic activity and dry weight biomass, which reached $9050 \mathrm{U} / \mathrm{mL} \pm 212$ and $11.05 \mathrm{~g} / \mathrm{L} \pm 0.12$, respectively. This is consistent with the findings of Khusro [29] who reported that yeast extract played a vital role in the production of the enzyme due to the presence of important elements and growth factors required for microorganisms [20]. Several studies have reported that the use of casein $1 \%(w / v)$ significantly affected the production of protease by bacteria [3]. The enhancement of protease production by B. stearothermophilus involved studying the effects of incubation time and inoculum size. First, we noticed that protease production was proportional to cell growth, with an optimum production of $5100 \mathrm{U} / \mathrm{mL}$ \pm 212 being obtained at $24 \mathrm{~h}$. Then, there was a rapid decrease in protease activity and cell growth by up to $72 \mathrm{~h}$ at a constant rate. This finding is in agreement with a previous report showing that the production of protease $(1900 \mathrm{U} / \mathrm{mL})$ is proportional to the bacterial growth, which was observed at $42 \mathrm{~h}$ of incubation [21]. Second, the protease activity was found to be proportional to the inoculum size tested, and the highest productivity $(5050 \mathrm{U} / \mathrm{mL})$ was observed with $8 \times 10^{8} \mathrm{CFU} / \mathrm{mL}$. After purification of the protease using reversed-phase analytical HPLC eurospher 100, C- 8 column $(250 \times 4.6 \mathrm{~mm})$, SDS-PAGE analysis of the obtained fractions clearly indicated that the protease possesses a molecular mass of approximately $28 \mathrm{kDa}$. The $\mathrm{N}$-terminal sequence of Ba.St.Pr exhibited a high level of identity of approximately $95 \%$ with those of Bacillus strains. Alignment of the Ba.St.Pr N-terminal sequence with the highest-identity protease sequences from Bacillus strains confirms that the current protease is serine protease. In fact, $95 \%$ identity was obtained with alkaline serine protease isolated from B. altitudinis, alkaline protease isolated from B. pumilus, serine alkaline protease isolated from B. circulans, serine protease isolated from Alkalihalobacillus lehensis, with the accession numbers APZ77034.1, QJX57841.1, ADN04910.1, and AFP23380.1, respectively. The 5\% difference in the aminoacids sequence with other bacillus proteases strongly suggested that the Ba.St.Pr enzyme was a novel serine protease.

The effects of extreme $\mathrm{pH}$ values and temperatures strongly argue the use of the pure protease obtained in this study in industrial applications. In fact, Ba.St.Pr exhibited the highest relative activity on casein at $\mathrm{pH} 10$ and $70{ }^{\circ} \mathrm{C}$. Moreover, studies on $\mathrm{pH}$ stability at alkaline values demonstrated that at $\mathrm{pH} 10$, Ba.St.Pr remains stable (90\%) for $10 \mathrm{~h}$ of incubation time. The thermal stability confirmed that Ba.St.Pr is extremely stable as it retained its activity at $80^{\circ} \mathrm{C}$ for $4 \mathrm{~h}$ when combined with $\mathrm{Ca}^{2+}$ and mannitol. The halflife time deduced from the thermal stability curves was approximately $123 \mathrm{~min}$ at $80^{\circ} \mathrm{C}$ for Ba.St.Pr alone, and it improved to 166 and $187 \mathrm{~min}$ when incubated with $\mathrm{Ca}^{2+}$ and the combination of $\mathrm{Ca}^{2+} /$ mannitol, respectively. Compared with proteases derived from Bacillus strains, the present study dealt with a thermostable protease. In fact, studies conducted on protease isolated from B. safensis reported that the half-life time measured at $70{ }^{\circ} \mathrm{C}$ was approximately $90 \mathrm{~min}$ in the presence of $2 \mathrm{mM} \mathrm{CaCl}_{2}$ [30]. 
Previous studies have described $\mathrm{Ca}^{2+}$ as a stabilizer of the activity and stability of proteases derived from Bacillus strains [31]. It has also been reported that polyols prevent the enzyme from denaturation by increasing some hydrophobic interactions within protein molecules [32]. Similarly, some surfactants, oxidizing agents, organic solvents, and ions are used in industrial applications. Thus, it is appreciable to produce resistant enzymes. In the present study, a higher stability of the enzyme was observed in the presence of Triton X-100, Tween 20, or Tween 80 , with an increase in its residual activities by $40 \%, 30 \%$, and $20 \%$, respectively. Moreover, we observed that Ba.St.Pr was remarkably stable in chloroform and ethanol as its activity was improved by $60 \%$, followed by that in DMF, isopropanol, and DMSO in which the residual enzyme activity was $100 \%$. The stability in the organic solvents argue the application of the novel protease in organic synthesis [14]. Furthermore, the enzyme showed very slight loss in its activity after exposure to various commercial detergents, suggesting its potential use as an additive in detergent formulations.

Consequently, all the evaluated activity parameters, including thermotolerance as well as tolerance to a varied range of $\mathrm{pH}$ values and stability of enzyme activity over a range of temperatures and $\mathrm{pH}$ values, are of interest to the detergent industry for use in the removal of proteinaceous stains. This enzyme can be applied in more than one specific industrial application, such as bioactive peptides used in the food and pharmaceutical industries.

\section{Materials and Methods}

\subsection{Protease Assay}

Enzyme activity was evaluated according to the method described by McDonald and Chen [33]. Briefly, $2 \mathrm{~mL}$ of $1 \%(w / v)$ casein in glycine-NaOH buffer $(\mathrm{pH} 10)$ was supplemented to $1 \mathrm{~mL}$ of enzyme and incubated at $60^{\circ} \mathrm{C}$ for $15 \mathrm{~min}$. Then, $3 \mathrm{~mL}$ of $10 \%$ TCA was added. The control sample contained $2 \mathrm{~mL}$ of $1 \%(w / v)$ casein solution, $1 \mathrm{~mL}$ of enzyme, and $3 \mathrm{~mL} 10 \%$ TCA $(w / v)$. Alkaline copper reagent $(5 \mathrm{~mL})$ was added to $1 \mathrm{~mL}$ of the incubated enzyme/substrate. After $15 \mathrm{~min}, 0.5 \mathrm{~mL}$ of Folin-Ciocalteu reagent was diluted in a 1:1 ratio and left to stand for $30 \mathrm{~min}$. The absorbance was read at $700 \mathrm{~nm}$. One unit of enzyme activity was defined as the amount of enzyme that released $1 \mu \mathrm{g}$ of tyrosine per $\mathrm{mL}$ per min under the above-described assay conditions.

\subsection{Effects of Culture Conditions on Bacterial Growth and Protease Production of the Isolate B. stearothermophilus}

The effects of different parameters on the cell growth and protease production of B. stearothermophilus were investigated. The physical and chemical parameters, such as carbon and nitrogen sources, temperature, initial $\mathrm{pH}$, inoculation size, and incubation period of the bacterium were analyzed according to the method described by Sepahy and Jabalameli [22] with few modifications. First, the cell growth was examined by measuring the optical density (OD) at $600 \mathrm{~nm}$. Optimization of the inoculum size ranging from $10^{8}$ to $8 \times 10^{8} \mathrm{CFU} / \mathrm{mL}$ under the culture conditions for protease production from B. stearothermophilus was examined using the method described by Sinha and Khare [34] at $\mathrm{pH} 10$ in a medium containing $5 \mathrm{~g}$ bactopeptone, $5 \mathrm{~g}$ yeast extract, $3 \mathrm{~g} \mathrm{NaCl}, 0.2 \mathrm{CaCl}_{2}, 5 \mathrm{~g} \mathrm{KH}_{2} \mathrm{PO}_{4}$, and $0.1 \mathrm{~g} \mathrm{FeSO}_{4} \cdot 7 \mathrm{H}_{2} \mathrm{O}$ dissolved in $1 \mathrm{~L}$ of distilled water. The inoculums were commonly grown in LB broth medium. Protease production assay was conducted as described previously [34] after centrifugation at $23,000 \times \mathrm{g}$ for $15 \mathrm{~min}$ at $4{ }^{\circ} \mathrm{C}$. The experiments were performed in triplicate. This method was applied to all the following parameters.

\subsubsection{Effect of Inoculum Size}

The effect of inoculum size on protease activity was analyzed as follows: $50 \mathrm{~mL}$ of the selected fermentation medium was inoculated with various amounts of inoculums ranging from $10^{8}$ to $8 \times 10^{8} \mathrm{CFU} / \mathrm{mL}(v / v)$ bacteria grown overnight. After $48 \mathrm{~h}$ of incubation, the protease activity was measured in the obtained culture filtrate. Media were incubated in a shaking incubator at $37^{\circ} \mathrm{C}$ for a period of 2 days and assessed for protease activity. 


\subsubsection{Effects of $\mathrm{pH}$ and Temperature:}

Briefly, approximately $8 \times 10^{8} \mathrm{CFU} / \mathrm{mL}$ was inoculated into sterilized LB broth, followed by incubation separately at various $\mathrm{pH}$ values ranging from 3 to 12 and various temperatures ranging from $30^{\circ} \mathrm{C}$ to $65^{\circ} \mathrm{C}$ for $24 \mathrm{~h}$ with $200 \mathrm{rpm}$ agitation. Both protease activity and bacterial biomass were evaluated.

\subsubsection{Effects of Carbon Sources:}

Several media were prepared at $\mathrm{pH} 10$ in $50-\mathrm{mL}$ flasks containing $1 \%(w / v)$ of selected carbon sources. Briefly, casein, xylose, glucose, starch, lactose, glucose, and galactose were tested separately for protease activity and dry weight measurement. The carbon source media were sterilized at $121{ }^{\circ} \mathrm{C}$ for $15 \mathrm{~min}$ before inoculation with $10 \%(v / v)$ B. stearothermophilus and incubated at $55^{\circ} \mathrm{C}$ for $24 \mathrm{~h}$ with $200 \mathrm{rpm}$ of agitation.

\subsubsection{Effects of Nitrogen Sources}

As described in the previous section, growth media were prepared containing $1 \%$ $(w / v)$ of the following selected nitrogen sources: ammonium nitrate, ammonium chloride, ammonium dehydrogenate phosphate, tryptone, peptone, or yeast extract. The media were set at $\mathrm{pH} 10$ and sterilized by autoclaving before inoculation with $10 \%(v / v)$ of bacteria and then incubated at $55^{\circ} \mathrm{C}$ for $24 \mathrm{~h}$.

\subsubsection{Effects of Incubation Time}

Microbial growth and enzyme production were investigated at various incubation times in the appropriate optimized medium. Samples were collected at a regular interval of 4 or $8 \mathrm{~h}$. Growth (OD) and protease activity were measured using a spectrophotometer.

\subsection{Protease Purification Procedure}

The isolated protease was purified using a combination of ammonium sulfate fractionation (30-65\%) precipitation, heat treatment $\left(80^{\circ} \mathrm{C}\right.$ for $\left.30 \mathrm{~min}\right)$, and reversed-phase RP-HPLC (Applied Biosystems, Foster City, CA, USA) on C-8 column. To remove microbial cells, $300 \mathrm{~mL}$ of a $24 \mathrm{~h}$ culture of B. stearothermophilus was centrifuged at $9000 \times \mathrm{g}$ for $30 \mathrm{~min}$. The extracellular protease was initially saturated with solid $\left(\mathrm{NH}_{4}\right)_{2} \mathrm{SO}_{4}$ at $30 \%$ after centrifugation at $10,000 \times g$ for $30 \mathrm{~min}$. The resulting supernatant was saturated up to $65 \%$ and recentrifuged and recuperated in $50 \mathrm{mM}$ Tris- $\mathrm{HCl}$ buffer containing $2 \mathrm{mM} \mathrm{CaCl}_{2}$ at $\mathrm{pH} 10$. The resuspended precipitate obtained after centrifugation at $15,000 \times \mathrm{g}$ for $30 \mathrm{~min}$ was subjected to a brief heat treatment step for $30 \mathrm{~min}$ at $80^{\circ} \mathrm{C}$, and the denatured material was removed by centrifugation at $10,000 \times g$ for $30 \mathrm{~min}$. The obtained supernatant exhibiting protease activity was loaded onto a reversed-phase RP-HPLC eurospher 100 (Applied Biosystems, Foster City, CA, USA), C-8 column $(250 \times 4.6 \mathrm{~mm})$, previously equilibrated with $0.1 \%$ TFA in water. Protein elution was performed with an acetonitrile linear gradient $(0-80 \%)$ at a flow rate of $1 \mathrm{~mL} / \mathrm{min}$ over $60 \mathrm{~min}$. The sample with the highest protease activity was collected, lyophilized, and stored at $4{ }^{\circ} \mathrm{C}$ until further use.

\subsection{Protein Analysis}

The protein content was determined at $595 \mathrm{~nm}$ using Bio-Rad DC Protein Assays (Hercules, CA, USA) using the Bradford method [35] with crystalline bovine serum albumin as a standard. The purity and molecular mass of the isolated protease were estimated by sodium dodecyl sulfate polyacrylamide gel electrophoresis (SDS-PAGE) using $15 \%$ polyacrylamide gels in the presence of $\beta$-mercaptoethanol as a reducing agent [36], and its $\mathrm{N}$-terminal sequence was determined using Edman's degradation technique as described by Hewick et al. [37].

\subsection{Amino Acid Sequencing}

The bands of purified Ba.St.Pr enzyme were separated on SDS gels and transferred to a ProBlott membrane (Applied Biosystems, Foster City, CA, USA), and the $\mathrm{NH}_{2}$-terminal 
sequence analysis was performed by automated Edman's degradation using a protein sequencer (Applied Biosystems Protein sequencer ABI Procise 492/610A) equipped with a 140C HPLC system (Applied Biosystems) according to standard operating procedures. The amino acid residues were detected as individual signals.

\subsection{Effects of $\mathrm{pH}$ and Temperature on Ba.St.Pr Activity and Stability}

The effects of $\mathrm{pH}$ and temperature on the activity and stability of pure protease were analyzed in the presence and absence of calcium ions ( $3 \mathrm{mM})$. First, buffers at $200 \mathrm{mM}$ concentration, corresponding to $\mathrm{pH}$ values ranging from 2 to 13 , were used to test the protease activity at $55{ }^{\circ} \mathrm{C}$. The $\mathrm{pH}$ stability of the purified protease was investigated by incubating the enzyme at various $\mathrm{pH}$ values ranging from 7 to 13 and at time intervals of 0-36 $\mathrm{h}$. The residual protease activity was determined using the standard assay method after removing the denatured proteins. Measurements were performed in triplicate. Second, the effect of temperature on protease activity was determined by evaluating the enzyme activity at temperatures ranging from $40{ }^{\circ} \mathrm{C}$ to $95{ }^{\circ} \mathrm{C}$ at $\mathrm{pH} 10$. Finally, to evaluate the thermal stability, pure protease was stored at extreme temperatures ranging from $70^{\circ} \mathrm{C}$ to $90^{\circ} \mathrm{C}$, at $\mathrm{pH} 10$, and for time periods ranging from 1 to $10 \mathrm{~h}$. The residual enzyme activity was measured after removing the denatured proteins.

\subsection{Performance Evaluation of Purified Ba.St.Pr}

\subsubsection{Effect of Organic Solvents on Enzyme Stability}

The organic solvent stabilities of the protease produced by B. stearothermophilus were investigated by incubating the enzyme preparation with different organic solvents at $25 \%$ $(v / v)$ for $24 \mathrm{~h}$ at $40^{\circ} \mathrm{C}$. The residual proteolytic activities were evaluated at $70{ }^{\circ} \mathrm{C}$ and $\mathrm{pH} 10$. The control (100\%) used in this study was the reaction mixture without any additives. The following organic solvents were tested: acetonitrile, benzene, chloroform, DMF, DMSO, ethanol, isopropanol, and methanol. A commercial protease (Alcalase 2.5 L, type DX) was used as a positive control.

\subsubsection{Effects of Surfactants and Oxidizing Agents on Enzyme Stability}

The effects of some neutral and charged surfactants (1\%) such as Tween 20, Tween 80 , Triton $\mathrm{X100}$, and NATDC on the stability of pure protease were investigated by incubating the enzyme preparation with various surfactants for $24 \mathrm{~h}$ at $40{ }^{\circ} \mathrm{C}$ under constant shaking at $160 \mathrm{rpm}$. The residual enzyme activity was assayed at $70{ }^{\circ} \mathrm{C}$ and $\mathrm{pH} 10$. The stability of the protease was also evaluated in the presence of oxidizing agents such as $\mathrm{H}_{2} \mathrm{O}_{2}$, sodium perborate, and sodium hypochlorite (1\%). The residual enzyme activity was measured under the same conditions and compared with a positive control (Alcalase $2.5 \mathrm{~L}$, type Dx, Novozymes A/S, Copenhagen, Denmark) and a negative control (the reaction mixture without any additives).

\subsubsection{Effects of Liquid and Solid Detergent on Enzyme Stability}

For evaluating the stability and compatibility of the protease with detergents, liquid and solid commercial detergents were diluted in tap water to obtain a final concentration of $7 \mathrm{mg} / \mathrm{mL}$ to simulate washing conditions. The endogenous proteolytic enzymes present in these laundry detergents were denatured by heat treatment of the diluted detergents at $90{ }^{\circ} \mathrm{C}$ for $1 \mathrm{~h}$. Next, $15 \mathrm{U} / \mathrm{mL}$ of the protease was incubated under shaking with each laundry detergent for $1 \mathrm{~h}$ at $40^{\circ} \mathrm{C}$, and the residual enzyme activity determined at $\mathrm{pH} 10$ and $70^{\circ} \mathrm{C}$ was compared to that of commercial Alcalase $2.5 \mathrm{~L}$, type Dx.

Author Contributions: Conceptualization, A.K. and M.A.; methodology, A.K.; software, A.B.B.; validation, A.B.B., and H.H.; formal analysis, A.K; investigation, H.H.; resources, M.A.; data curation, A.K.; writing-original draft preparation, A.K.; writing—review and editing, H.H. and A.B.B.; visualization, M.A.; supervision, A.K.; project administration, A.B.B. All authors have read and agreed to the published version of the manuscript. 
Funding: This research received no external funding.

Institutional Review Board Statement: Not applicable.

Informed Consent Statement: Not applicable.

Data Availability Statement: The data presented in this study are available on request from the corresponding author.

Acknowledgments: The authors extend their appreciation to the researchers Supporting Project number (RSP-2020/237), King Saud University, Riyadh, Saudi Arabia, for funding this work.

Conflicts of Interest: The authors declare no conflict of interest.

Sample Availability: Samples of the compounds are not available from the authors.

\section{References}

1. Kuddus, M.S.; Singh, P.; Thomas, G.; Al-Hazimi, A. Recent developments in production biotechnological applications of, C-phycocyanin. BioMed Res. Int. 2013, 2013, 742859. [CrossRef]

2. Ahmed, Z.D.; Donkor, O.; Street, W.A.; Vasiljevic, T. Proteolytic activities in fillets of selected underutilized Australian fish species. Food Chem. 2013, 140, 238-244. [CrossRef] [PubMed]

3. Sharma, K.M.; Kumar, R.; Panwar, S.; Kumar, A. Microbial alkaline proteases: Optimization of production parameters and their properties. J. Genet. Eng. Biotechnol. 2017, 15, 115-126. [CrossRef] [PubMed]

4. Tufvesson, P.; Lima-Ramos, J.; Nordblad, M.; Woodley, J.M. Guidelines and cost analysis for catalyst production in biocatalytic processes. Org. Process. Res. Dev. 2011, 15, 266-274. [CrossRef]

5. Belmessikh, A.B.; Boukhalfa, H.; Mechakra-Maza, A.; Gheribi-Aoulmi, Z.; Amrane, A. statistical optimization of culture medium for neutral protease production by Aspergillus oryzae. Comparative study between solid and submerged fermentations on tomato pomace. J. Taiwan Inst. Chem. Eng. 2013, 44, 377-385. [CrossRef]

6. Bach, E.S.A.; Sant'Anna, V.; Daroit, D.J.; Corrêa, A.P.F.; Segalin, J.; Brandelli, A. Production, one-step purification, and characterization of a keratinolytic protease from Serratia marcescens P3. Process. Biochem. 2012, 47, 2455-2462. [CrossRef]

7. Helal, M.M.I.; Amer, H.; Abdelwahed, N.A.M.; Ghobashy, M.O.I. Physiological and microbiological studies on production of alkaline protease from locally isolated Bacillus subtilis. Aust. J. Basic Appl. Sci. 2012, 6, 193-203.

8. Harwood, C.R.; Cranenburgh, R. Bacillus protein secretion: An unfolding story. Trends Microbiol. 2008, 16, 73-79. [CrossRef]

9. Duman, R.E.; Löwe, J. Crystal structures of $€$ Bacillus subtilis lon protease. J. Mol. Biol. 2010, 401, 653-670. [CrossRef]

10. Feldman, L.A. Preparation of Microbial Alkaline Protease by Fermentation with Bacillus Subtilis, Variety Licheniformis. U.S. Patent 3623957, 30 November 1971.

11. Rehman, R.A.; Ahmed, M.; Siddique, A.; Hasan, F.; Hameed, A.; Jamal, A. Catalytic role of thermostable metalloproteases from Bacillus subtilis KT004404 as dehairing and destaining agent. Appl. Biochem. Biotechnol. 2017, 181, 434-450. [CrossRef]

12. Anandharaj, M.S.; Sivasankari, B.; Siddharthan, N.A.; Rani, R.P.; Sivakumar, S. Production, purification, and biochemical characterization of thermostable metallo-protease from novel Bacillus alkalitelluris TWI3 isolated from tannery waste. Appl. Biochem. Biotechnol. 2016, 178, 1666-1686. [CrossRef]

13. Annamalai, N.R.; Rajeswari, M.V.; Thavasi, R.; Vijayalakshmi, S.; Balasubramanian, T. Optimization, purification and characterization of novel thermostable, haloalkaline, solvent stable protease from Bacillus halodurans CAS6 using marine shellfish wastes: A potential additive for detergent and antioxidant synthesis. Bioprocess. Biosyst. Eng. 2013, 36, 873-883. [CrossRef]

14. Bougatef, A.B.; Balti, R.; Haddar, A.; Jellouli, K.; Souissi, N.; Nasri, M. Protein hydrolysates from bluefin tuna (Thunnus thynnus) heads as influenced by the extent of enzymatic hydrolysis. Biotechnol. Bioprocess Eng. 2012, 17, 841-852. [CrossRef]

15. Ozcan, T.K.; Kurdal, E. The effects of using a starter culture, lipase, and protease enzymes on ripening of Mihalic cheese. Int. J. Dairy Technol. 2012, 65, 585-593. [CrossRef]

16. Caille, J.C.; Govindan, C.K.; Junga, H.; Lalonde, J.; Yao, Y. Hetero diels-alderbiocatalysis approach for the synthesis of (s)-3-[2$\{($ methylsulfonyl) oxy\} ethoxy]-4-(triphenylmethoxy)-1-butanol methanesulfonate, a key intermediate for the synthesis of the pkc inhibitor. Org. Process. Res. Dev. 2002, 6, 471-476. [CrossRef]

17. Rahman, R.; Salleh, A.; Basri, M. Production of Protease from Bacillus stearothermophilus F1. U.S. Patent 20050186661, 18 February 2005.

18. Hawumba, J.F.T.; Theron, J.; Brözel, V.S. Thermophilic Protease-Producing Geobacillus from Buranga Hot Springs in Western Uganda. Curr. Microbiol. 2002, 45, 144-150. [CrossRef]

19. Shanthakumari, A.R.; Bominathan, M. Studies on screening of Bacillus sp. for protease production. Int. J. Theor. Appl. Sci. 2017, 9 , 294-299.

20. Khusro, A. One Factor at A Time based optimization of protease from poultry associated Bacillus licheniformis. J. Appl. Pharm. Sci. 2016, 6, 88-95. [CrossRef]

21. Thebti, W.; Riahi, Y.; Belhadj, O. Purification and characterization of a new thermostable, Haloalkaline, solvent stable, and detergent compatible serine protease from Geobacillus toebii Strain LBT 77. BioMed Res. Int. 2016, 2016, 1-8. [CrossRef] [PubMed] 
22. Akhavan Sepahy, A.; Jabalameli, L. Effect of culture conditions on the production of an extracellular protease by Bacillus sp. Isolated from soil sample of Lavizan jungle park. Enzym. Res. 2011, 2011, 1-7.

23. Derekova, A.M.; Mandeva, R.; Kambourova, M. Phylogenetic diversity of thermophilic carbohydrate degrading bacilli from Bulgarian hot springs. World J. Microbiol. Biotechnol. 2008, 24, 1697-1702. [CrossRef]

24. Malathi, S.C.; Appl, R. Production of alkaline protease by a new Aspergillus flavus isolate under solid-substrate fermentation conditions for use as a depilation agent. Environ. Microbiol. 1991, 57, 712-716. [CrossRef]

25. Tsuchiya, K.; Sakashita, H.; Nakamura, Y.; Kimura, T. Production of thermostable alkaline protease by alkalophilic Thermoactinomyces sp. HS682. Agric. Biol. Chem. 1991, 55, 3125-3127. [CrossRef]

26. Phadatare, S.U.D.; Deshpande, V.V.; Srinivasan, M.C. High activity alkaline protease from Conidiobolus coronatus (NCL 86.8.20): Enzyme production and compatibility with commercial detergents. Enzym. Microb. Technol. 1993, 15, 72-76. [CrossRef]

27. Frankena, J.; Van Verseveld, H.W.; Stouthamer, A.H. A continuous culture study of the bioenergetic aspects of growth and production of exocellular protease in Bacillus licheniformis. Appl. Microbiol. Biotechnol. 1985, 22, 169-176. [CrossRef]

28. Hidayat, M.Y.; Saud, H.M.; Samsudin, A.A. Isolation and characterisation of Sulphur oxidizing bacteria isolated from hot spring in Malaysia for biological deodorisation of hydrogen sulphide in chicken manure. Media Peternak. 2017, 40, 178-187. [CrossRef]

29. Yang, S.H.; Cho, J.K.; Lee, S.Y.; Abanto, O.D.; Kim, S.K.; Ghosh, C.; Lim, J.S.; Hwang, S.G. Isolation and characterization of Novel denitrifying bacterium Geobacillus sp. SG-01 strain from wood chips composted with swine manure. Asian-Australas. J. Anim. Sci. 2013, 26, 1651-1658.

30. Rekik, H.; Jaouadi, N.Z.; Gargouri, F.; Bejar, W.; Frikha, F.; Jmal, N.; Bejar, S.; Jaouadi, B. Production, purification and biochemical characterization of a novel detergent-stable serine alkaline protease from Bacillus safensis strain RH12. IJBM 2019, 121, 1227-1239. [CrossRef] [PubMed]

31. Alcaraz, L.D.; Olmedo, G.; Bonilla, G.; Cerritos, R.; Hernández, G.; Cruz, A.; Ramírez, E.; Putonti, C.; Jiménez, B.; Martínez, E.; et al. The genome of Bacillus coahuilensis reveals adaptations essential for survival in the relic of an ancient marine environment. Proc. Nat. Acad. Sci. USA 2008, 105, 5803-5808. [CrossRef]

32. Yamane, T.K.; Kani, T.; Hatanaka, T.; Suzuki, A.; Ashida, T.; Kobatashi, T.; Ito, S.; Yamashita, O. Structure of a new alkaline serine protease (M-protease) from Bacillus sp. KSM-K16. Acta Cryst. Sect. D Acta Cryst. 1995, 51, 199-206. [CrossRef]

33. McDonald, C.E.C.; Chen, L.L. The Lowry modification of the Folin reagent for determination of proteinase activity. Anal. Biochem. 1965, 10, 175-177. [CrossRef]

34. Sinha, R.K.; Khare, S.K. Characterization of detergent compatible protease of a halophilic Bacillus sp. EMB9: Differential role of metal ions in stability and activity. Bioresour. Technol. 2013, 145, 357-361. [CrossRef] [PubMed]

35. Bradford, M.M. A rapid and sensitive method for quantitation of microgram quantities of protein utilizing the principle of protein-dye binding. Anal. Biochem. 1976, 72, 248-254. [CrossRef]

36. Laemmli, U.K. Cleavage of structural proteins during the assembly of the head of bacteriophage T4. Nature 1970, 227, 680-685. [CrossRef]

37. Hewick, R.M. I-Iunkapiller, MW; Hood, LE; Dreyer, WJ. Bioi. GCIII 1981, 256, 7990-7997. 